\title{
Effect of Cooking on Quality Commonly Consumed Marine Fish Platycephalidae (Platycephalus indicus) in Iran
}

\author{
Ali Aberoumand", Saeed Ziaei-Nejad \\ Department of Fisheries, Behbahan Khatam Alanbia University of Technology, Behbahan, Iran
}

\begin{tabular}{|c|c|}
\hline A R T I C LE INFO & A B S T R A C T \\
\hline $\begin{array}{l}\text { Article history: } \\
\text { Received } 15 \text { March } 2015 \\
\text { Accepted } 203 \text { November } 2015 \\
\text { Available online, ISSN: } 2148-127 \mathrm{X}\end{array}$ & $\begin{array}{l}\text { Fish Platycephalus indicus usually are consumed by southern people in Iran. The present } \\
\text { study assessed the effect of processing on proximate compositions in the fillets of } \\
\text { P.indicus. The fish samples were prepared by boiling, baking and frying, while proximate } \\
\text { analysis was done by standard methods. Boiling processing method significantly } \\
\text { reduced ash content in the fillet whereas fat content was significantly increased in frying. }\end{array}$ \\
\hline $\begin{array}{l}\text { Keywords: } \\
\text { Fish } \\
\text { P. indicus }\end{array}$ & $\begin{array}{l}\text { concentration was obtained for boiled fillet }(82.73 \%) \text {. Lipid content was recorded highest } \\
\text { in fried fillet }(17.27 \%) \text {. P. indicus was, rich in fat, protein, and ash, thus its consumption } \\
\text { should be encouraged. }\end{array}$ \\
\hline
\end{tabular}

Cooking effect

Proximate composition

"Corresponding Author:

E-mail: aberoumandali@yahoo.com

\section{Introduction}

In general fish well known as an excellent source of high biological level protein in the human diet. Fish is widely consumed in many parts of the world by humans not only for its high quality protein content but also for the low saturated fat. It contains important n-3 polyunsaturated fatty acids that are likely to lower the risk of heart diseases in adults and are important for neurodevelopment in infants and young, and are known to support good health (Uauy et al. 2003).

Fish is always cooked in different methods before consumption. Cooking (boiling, baking, roasting, frying and grilling) improves hygienic quality of the fish by inactivation of pathogenic microorganisms and enhances digestibility of nutrients in the digestive tract. Frying is one of the oldest way of food preparation. It improves the sensory quality of food by formation of aroma compounds, attractive color and texture. Cooking can be both beneficial and detrimental to nutrient content of fish. During cooking, chemical and physical reactions take place which either improve or impair the fish nutritional value (e.g. digestibility is increased because of protein denaturation in fish) but the content of thermo labile compounds, fat-soluble vitamins or polyunsaturated fatty acids is often reduced (Bognár, 1998).
Since fish is not normally consumed raw, different processing methods are employed in preparing them for consumption and some of these processes, which could have varying effects on their nutrient contents, texture and flavor (Eriksson, 1987).

In Iran, species $P$. indicus usually processed by various cooking methods, before consumption. Heating process (boiling, baking and frying) is applied to enhance texture and taste of fishes and inactivate pathogenic microorganisms (Bognár, 1998). The use of the microwave oven grilling method of cooking has increased greatly during the recent decades (Garcia-Aria et al. 2003a). The different cooking methods invariably affect the nutritive value of fish and especially vitamins, flavor compounds and polyunsaturated fatty acids. The effects of various cooking methods on proximate composition of several fish species have been reported (Ersoy et al. 2006; Gokoglu et al. 2004; Kucukgulmez et al. 2006; Rosa et al. 2007; Stephen et al. 2010; Weber et al. 2008). Up to now there is no information available in the literature on the nutritive values of raw and cooked selected fish species. Hence the present study was aimed to investigate the effects of various cooking methods on the proximate and mineral composition of P.indicus. The possible effects of 
various cooking methods on the nutritive value of this species were evaluated; the values obtained in the cooked samples were compared with the values found in raw fish.

\section{Materials and Methods}

\section{Samples Preparation and Cooking}

A eight of pieces fish species Platycephalidae $(P$. indicus), with a length $(44.5-48.5 \mathrm{~cm})$ and weight of $(1 \mathrm{~kg})$ were obtained from the local fish market in Behbahan, Khuzestan, Iran. They were kept in a plastic container and transported to the laboratory. In the laboratory, the fish was washed with tap water three times to remove wastes. The fish was then placed in ice-cold water for six minutes prior to eviscerating and beheading. Two pieces fish used for each processing. Subsequently the fish samples were filleted and fillets were divided into four groups and each group consisted of four fillets. The first group was uncooked while the other three groups were cooked in the following methods; boiling, baking, and frying. Boiling was performed at $99-101^{\circ} \mathrm{C}$ for 12 min. Baking of fillets was performed in a conventional oven with the temperature set at $200^{\circ} \mathrm{C}$ for $20 \mathrm{~min}$. The frying of fillets was performed in a domestic frying pan of $2 \mathrm{~L}$ capacity at temperature approximately of $180^{\circ} \mathrm{C}$ for 15 min. Sunflower oil was used for frying. The fresh and cooked fishes were ground in a kitchen blender to ensure homogeneity and representative samples taken for analysis. Samples were packed in a polythene bags and kept under frozen conditions $\left(-20{ }^{\circ} \mathrm{C}\right)$ until analysis.

\section{Proximate Analyses}

The moisture, ash, crude fat, crude protein $(\mathrm{N} \times 6.25)$ and carbohydrate (by difference) were determined in accordance with AOAC methods (AOAC. 2000). All proximate analyses of the fish samples were carried out in triplicate.

\section{Statistical Analysis}

The effect of different cooking methods on the proximate composition of selected fish species was analyzed using one-way analysis of variance (ANOVA) and the significant differences between means were determined by post hoc Duncan's multiple range test. Differences were considered to be significant when $\mathrm{P}<0.05$. Data were analyzed using SPSS package (Version 11).

\section{Results}

The proximate composition of raw fish and the fillets after various cooking methods of, Platycephalidae $(P$. indicus) are presented in Table 1. Comparison of processed fillets weight (g/100) after doing all processing methods with raw fish fillets are presented in Table 2.

\section{Discussion}

The proximate composition of raw fillets is similar to earlier reports in Platycephalidae fish (Zuraini et al. 2006). Proximate composition of protein, fat and ash of $P$. indicus was varied in all the cooking methods. Significantly higher protein content (82.73\%) was recorded in boiled fillets followed by $(70.96 \%)$ in frying than the rest of the cooking methods and raw fish fillets $(\mathrm{P}<0.05)$. Significantly higher fat content $(17.27 \%)$ was observed in fried fillets $(\mathrm{P}<0.05)$. There was no significant difference observed in fat content among boiled, baked and fried fish fillets except raw fish fillet $(\mathrm{P}>0.05)$. The increase in fat content of the fried fish fillets is related to oil absorption during the cooking process. Further the increase of fat content can be attributed to the oil penetration on the food after water is partially lost by evaporation (Saguy and Dana, 2003). Similar results were reported for sardine and African catfish fried in vegetable oil (Candela et al. 1996). Table 2 showed that loss of moisture in fried fish fillets was more than boiled and baked fish fillets respectively. Therefore, nutritive values of baked and boiled fish fillets can be higher than fried fish fillets, but obtained results in Table 1 showed that energetic value of boiled fish fillets $(407.34 \pm 1.26 \mathrm{kcal} / 100 \mathrm{~g})$ was more than baked fish fillets $(337.56 \pm 1.67 \mathrm{kcal} / 100 \mathrm{~g})$, but highest value $(445.43+1.89$ $\mathrm{kcal} / 100)$ found for fried fillets, because absorption of fat by fillet in frying process.

Table 1 Proximate (\%) composition (in DM powder) of raw and cooked fillets samples of $P$. indicus

\begin{tabular}{l|rrrr}
\hline Items & \multicolumn{1}{c}{ Raw } & \multicolumn{1}{c}{ Boiled } & \multicolumn{1}{c}{ Baked } & Fried \\
\hline Protein & $78.82 \pm 1.56^{\mathrm{a}}$ & $82.73+0.98^{\mathrm{b}}$ & $70.28 \pm 1.62^{\mathrm{c}}$ & $70.96+0.88^{\mathrm{c}}$ \\
Lipid & $9.74 \pm 0.66^{\mathrm{a}}$ & $7.74 \pm 0.71^{\mathrm{a}}$ & $5.52 \pm 0.22^{\mathrm{a}}$ & $17.27 \pm 0.31^{\mathrm{b}}$ \\
Ash & $9.59 \pm 0.34^{\mathrm{a}}$ & $7.84 \pm 0.21^{\mathrm{b}}$ & $10.64 \pm 0.56^{\mathrm{a}}$ & $10.11 \pm 0.22^{\mathrm{a}}$ \\
Carbohydrate & $1.85 \pm 0.01^{\mathrm{a}}$ & $1.69+0.23^{\mathrm{a}}$ & $1.45 \pm 0.11^{\mathrm{a}}$ & $1.54 \pm 0.23^{\mathrm{a}}$ \\
Energetic value(Kcal/100g) & $410.34 \pm 1.23^{\mathrm{a}}$ & $407.34 \pm 1.26^{\mathrm{a}}$ & $337.56 \pm 1.67^{\mathrm{b}}$ & $445.43 \pm 1.89^{\mathrm{c}}$ \\
\hline
\end{tabular}

Values are shown as mean \pm standard deviation of triplicates. Values within the same row have different superscripts are significantly different $(\mathrm{P}<0.05)$.

Table 2 Comparison of processed fillets weight ( $\mathrm{g} / 100)$ after doing all processing methods with raw fish fillets

\begin{tabular}{l|cccc}
\hline Sample & Raw & Boiled & Baked & Fried \\
\hline Platycephalus indicus & 100 & 90.72 & 93.44 & 84.90 \\
\hline \multicolumn{2}{l}{ Values are shown as mean of triplicates }
\end{tabular}


The increase in dry matter content was observed in boiled fillets. Increased ash content were found in all the cooked fillets except for the boiled fillet. Moisture loss was found in boiled fillets. However, dehydration rate was low during frying and baking. These changes were similar to those reported by Gokoglu et al. (2004) in rainbow trout and Garcia-Arias et al. (2003b) in sardines. Water losses, occurring during frying and baking resulted in higher protein content in fried and baked fish as compared to the raw fish fillets (Garcia-Arias, et al. 2003b). Accordingly, the increase in ash, protein and fat content found in cooked silver catfish fillets is explained by the reduction in moisture. Differences in water contents between fresh and smoked rainbow trout were found to be significant (Unlusayin, et al. 2001).This findings also supported by Gall et al.(1983), that deep fried fish fillet had significantly higher protein content than raw fillet.

\section{Conclusion}

It is concluded all the processing methods examined for preparation of fish for human consumption that frying is the best when preservation of the fish is of priority but when nutrient conservation and safety diet is the focus, boiling is a better option.

\section{Acknowledgements}

Authors thank the Behbahan Technology University for financially supporting this work.

\section{Funding/Support}

This work was funded by the Behbahan Technology University, Iran.

\section{References}

AOAC. 2000. Official methods of analysis. 13Th ed. Washington DC: Association of Official Analytical Chemist.

Bognár A. 1998. Comparative Study of Frying to other Cooking Techniques Influence on The Nutritive Value. Grasas Aceites 49:3-4.

Candela M, Astiasaran I, Bello J. 1996. Effects of frying and warm holding on fatty acids and cholestrol of sole (Solea solea) codfish (Gadus morhua) and hake (Merluccius merluccius) Food Chemistry 58(3):227-231.

Eriksson CE. 1987. Oxidation of lipids in food systems. In: Autoxidation of unsaturated lipids. HWS Chan (Ed). 207 231.Academic press, London.
Ersoy B, Yanar Y, Kucukgulmez A, Celik M. 2006. Effects of four cooking methods on the heavy metal concentrations of sea bass fillets (Dicentrarchus labrax Linne, 1785) Food Chemistry 99(4):748-751.

Gall KL, Otwell WS, Koburger JA, Appledorf H. 1983. Effects of four cooking methods on proximate, mineral and fatty acid composition of fish fillets. Journal of Food Science 48:10681074.

Garcia Arias MT, Pontes EA, Fernandez MCG, Muniz FJS. 2003a. Freezing/ defrosting/frying of sardine fillets. Influence of slow and quick defrosting on protein quality. Journal of Science Food Agricultural 83:602-608.

Garcia-Arias MT, Pontes EA, Garcia-Linares MC, GarciaFernandez MC, Sanchez-Muniz FJ. 2003b. Cooking-freezingreheating (CFR) of sardine (Sardina pilchardus) fillets. Effect of different cooking and reheating procedures on the proximate and fatty acid compositions. Food Chemistry 83:349-356.

Gokoglu N, Yerlikaya P, Cengiz E. 2004. Effects of cooking methods on the proximate composition and mineral contents of rainbow trout (Oncorhynchus mykiss) Food Chemistry 84:1922.

Gokoglu N, Yerlikaya P, Cengiz E. 2004. Effects of cooking methods on the proximate composition and mineral contents of rainbow trout (Oncorhynchus mykiss) Food Chemistry 84:1922.

Kucukgulmez A, Celik M, Yanar Y, Ersoy B, Cikrıkcı M. 2006. Effects of different cooking methods on the proximate composition and mineral contents of sea bass (Dicentrarchus labrax) Advanced Food Science 28(4):223-227.

Rosa R, Bandarra NM, Nunes ML. 2007. Nutritional quality of African catfish Clarias gariepinus (Burchell1822): A positive criterion for the future development of the European production of Siluroidei. International Journal of Food Science and Technology 42:342-351.

Saguy IS, Dana D. 2003. Integrated approach to deep fat frying: Engineering, nutrition, health and consumer aspects. Journal of Food Engineering 56:143-152.

Stephen NM, Shakila RJ, Jeyasekaran G, Sukumar D. 2010. Effect of different types of heat processing on chemical changes in tuna. Journal of Food Science and Technology 47(2):174-181.

Uauy R, Hoffman DR, Mena P, Llanos A, Birch EE. 2003. Term infant studies of DHA and ARA supplementation on neurodevelopment: Results of randomized controlled trials. Journal of of Pediat 143(4):17-25.

Unlusayin M, Kaleli S, Gulyavuz H. 2001. The determination of flesh productivity and protein components of some fish species after hot smoking. Journal of Science of Food and Agricultural 81:661-664.

Weber J, Bochi VC, Ribeiro CP, Victorio AM, Emanuelli T. 2008. Effect of different cooking methods on the oxidation, proximate and fatty acid composition of silver catfish (Rhamdia quelen) fillets. Food Chemistry 106:140-146.

Zuraini A, Somchit MN, Solihah MH, Goh YM, Arifah AK, Zakaria MS, Somchit N, Rajion MA, Zakaria ZA, Mat Jais AM. 2006. Fatty acid and amino acid composition of three local Malaysian Channa spp. Food Chemistry 97:674-678. 